\title{
PATHOGENICITY OF MYCOGONE PERNICIOSA ISOLATES COLLECTED ON POLISH MUSHROOM FARMS
}

\author{
Joanna SZUMIGAJ-TARNOWSKA*, Czesław ŚLUSARSKI, Zbigniew ULIŃSKI \\ Research Institute of Horticulture \\ Konstytucji 3 Maja 1/3, 96-100 Skierniewice, Poland
}

Received: May 2015; Accepted: June 2015

\begin{abstract}
Mycogone perniciosa is the fungal pathogen causing the wet bubble of white button mushrooms (Agaricus bisporus). The main symptoms of disease are undifferentiated, irregular forms of mushroom tissue, cap spotting and development of amber liquid droplets on the distorted mushrooms. The aim of the research was to assess the pathogenicity of $M$. perniciosa isolates that were obtained from the infected sporophores. Six isolates from Polish mushroom farms as well reference strain of Hypomyces perniciosus CBS 322.52 were used in this study. The pathogenicity of isolates was assessed on the basis of severity of disease symptoms and crop reduction in the first flush. Mushroom crop was infected with different suspensions containing of $M$. perniciosa aleuriospores. Significant variability was shown between tested isolates. It was stated that the pathogenicity of isolates and concentration of conidia had a significant influence on the mushroom yield. The isolate of high pathogenicity caused significant yield losses, after inoculation with $1.3 \times 10^{4} \cdot \mathrm{m}^{-2}$, whereas the isolate with fairly pathogenicity did not produce symptoms of wet bubble disease or caused slight deformation of single sporophores, even when the casing soil was inoculated with $1.3 \times 10^{6} \cdot \mathrm{m}^{-2}$ spores.
\end{abstract}

Key words: Mycogone perniciosa, Agaricus bisporus, wet bubble, strain pathogenicity, yield reduction

\section{INTRODUCTION}

Poland is the biggest producer of the white button mushroom (Agaricus bisporus) in Europe and the major exporter of fresh mushrooms in the world. Mushroom production in 2014 amounted to more than 300000 tons (Szudyga 2015). In spite of careful farm management and stringent hygiene measures the diseases are very difficult to control, because most fungicides used in the past are no longer approved. Thereby bacterial and fungal diseases are a serious problem in white button mushroom cultivation, which have a significant influence on quality and yield of mushrooms. Mycogone perniciosa (Magnus) Delacroix (teleomorph Hypomyces perniciosus) is the fungal pathogen of white button mushroom, causing wet bubble disease, which is considered as one of the most important disease of A. bisporus cultivation (Fletcher et al. 1975; Szumigaj-Tarnowska et al. 2012). Smith (1924) revealed that the first scientific record of the disease caused by Mycogone spp. was described by Magnus in 1888. Subsequently, Constantin \& Dufour in 1892 made an exhaustive study of this disease and named the pathogen as $M$. perniciosa (Magnus) (Smith 1924). In Poland, the wet bubble disease occurs quite frequently and may induce from $10 \%$ to $46 \%$ loss in yield, especially if infection occurs in the first flush (Maszkiewicz 2001; Ślusarski et al. 2012). A complete lack of the yield has also been observed by Maszkiewicz and Dyki (1988). The pathogen may infect $A$. bisporus at various stages of its development. Infection at pinhead-stage resulted in undifferentiated, large, irregular forms of mushroom tissue (called sclerodermoid mushrooms) covered with the pathogen's white and fluffy myce- 
lium; later infections lead to deformation of the carpophores and cap spotting (Fletcher \& Ganney 1968; Hsu \& Han 1981). The characteristic symptom of the disease is also the presence of amber liquid droplets on the surface of distorted mushrooms. It is recognized that the early development of wet bubble is usually associated with the use of infected casing soil or spawn (Fletcher et al. 1989; Sharma \& Kumar 2005).

M. perniciosa produces two types of conidia: small, one-celled, thin-walled phialoconidia and much larger bicellular conidia (aleuriospores), which consist of a dark, spherical thick-walled, verrucose apical cell situated on a thin-walled basal cell. Phialoconidia are formed at the tip of phialides, like in Verticillium, whereas aleuriospores develop on short, lateral hyphae. Conidiophores are branched and cylindrical like those of Verticillium (Glamoclija et al. 2008; Potocnik 2006).

The development of infection caused by M. perniciosa depends on various conditions, like temperature and relative air humidity in growing rooms as well as the pathogenicity of isolates. Fletcher et al. (1995) showed that pathogenic isolates of M. perniciosa are slow-growing on agar and their mycelium is pigmented, because it produces numerous aleuriospores whereas, weakly pathogenic isolates are characterized by fast growth on medium and little pigmented mycelium.

In this study, we examined the pathogenicity of six - M. perniciosa isolates on the basis of disease symptoms severity and the yield reduction after casing spraying with spore suspension containing various numbers of aleuriospores.

\section{MATERIALS AND METHODS}

\section{Isolates}

M. perniciosa isolates used in this study were obtained in 2008 from diseased fruit-bodies of A. bisporus. The infected mushrooms were obtained from A. bisporus cultivations situated in the mazowiecki region of Poland (isolates M1, M9, M18, M19) and siedlecki region (isolate M11). The identification of the isolated fungi was based on morphological characteristics as well as on growth rates and aspects of the colony on various agar media. To confirm the identification of pathogen the molecular analysis was also conducted (Szumigaj-Tarnowska et al. 2013a). The reference isolate Hypomyces perniciosus CBS 322.52 was obtained from international culture collections Centraalbureau voor Schimmelcultures (CBS, Utrecht, The Netherlands).

For isolation of the pathogen, $5 \mathrm{~mm}$ discs of infected sporophore tissue, with the help of sterilized scalpel were taken, and placed on potato dextrose (PDA) medium supplemented with $50 \mathrm{mg} \cdot \mathrm{l}^{-1}$ of streptomycin and $5 \mathrm{mg} \cdot \mathrm{l}^{-1}$ rifampicin. Mycelium was grown at $23-24{ }^{\circ} \mathrm{C}$ for one week. For further studies the isolates were maintained for short term on PDA medium at $4{ }^{\circ} \mathrm{C}$ and on PDA medium placed in $15 \% \mathrm{v} / \mathrm{w}$ glycerol at $-75{ }^{\circ} \mathrm{C}$ for long storage. Before analysis the isolates were activated on PDA medium at temperature $23-24^{\circ} \mathrm{C}$. Once a year fungal isolates were inoculated on the white button mushroom to enhance their pathogenicity.

\section{Mushroom cultivation and infection experiments}

The pathogenic trials were carried out in pots, $22 \mathrm{~cm}$ in diameter (surface area $0.038 \mathrm{~m}^{2}$ ), filled with $1.7 \mathrm{~kg}$ of compost phase III spawned with A15 mushroom strain, which was characterized as moderately susceptible to wet bubble disease (SzumigajTarnowska et al. 2013b). Then the surface of the compost was covered with a $4 \mathrm{~cm}$ layer of medium type casing, constituted blend of different peats. The conditions in the mushroom house chamber were fully controlled as for routine production, that is, temperature was $24{ }^{\circ} \mathrm{C}$, carbon dioxide concentration was $3000 \mathrm{mg} \cdot \mathrm{l}^{-1}$ and a relative humidity was 95\%. After 8 days, when the mycelium reached the surface of the casing, the temperature and carbon dioxide concentrations were lowered to $18{ }^{\circ} \mathrm{C}$ and to $800 \mathrm{mg} \cdot \mathrm{l}^{-1}$, respectively. Then the casing surface was sprayed with $5 \mathrm{ml}$ of aleuriospores suspension containing $1 \times 10^{2} ; 1 \times 10^{3}$ or $1 \times 10^{4}$ spores per $\mathrm{ml}$ (Van Zaayen \& Van Adrichem 1982), which corresponded to $1.3 \times 10^{4} ; 1.3 \times 10^{5}$ and $1.3 \times 10^{6}$ spores per $1 \mathrm{~m}^{2}$ of the casing. Cultivations carried out in pots which were not infected by $M$. perniciosa spores were treated as the control.

In order to examine the isolates pathogenicity, the disease severity and yield of mushrooms was investigated in the first flush. The severity and development of disease (disease severity index - DSI) 
was established also based on a 0-4 scale, in which: 0 - no disease symptoms, 1 - single sporophores with disease symptoms, $2-10-39 \%$ of infected crop, $3-40-69 \%$ of infected crop, $4-70-100 \%$ of infected crop.

\section{Statistical method}

Two series of two-factorial (type of isolate $x$ spores concentration) experiment with four replications were carried out in ten months interval. Data were not normally distributed and were analysed using a nonparametric Kruskal Wallis test at the level of significance of $p=0.05$. The means separation were done using Dunn's test of multiple comparisons. To evaluate the relation between the disease severity index and mushroom yield a regression method was used and Pearson's correlation coefficients (r-values) were calculated.

\section{RESULTS AND DISCUSSION}

The first symptoms of wet bubble disease, that is, slight deformations of mushroom tissue and appearance of brown masses on casing were noticed 14 days after inoculation at the beginning of pinhead formations. The severity of symptoms depended on the type of isolate and spores concentration (Table 1). The isolates CBS and M19 at spores concentration $1.3 \times 10^{4} \cdot \mathrm{m}^{-2}$ did not cause disease symptoms in the first flush. The applying of isolates M18 and M1 1 resulted in the deformation of single sporophores (average scale of infection was 0.75 ), while M1 and M9 isolates caused the highest infestation severity ( 2 and 3.25 , respectively). The higher number of spores, that is, $1.3 \times 10^{5} \cdot \mathrm{m}^{-2}$, did not cause any disease symptoms only for CBS isolate. The application of M19 isolate at above concentration resulted in the deformation of single sporophores only with an average scale infection 0.5 . The remaining isolates caused characteristic symptoms of wet bubble disease, scored from 2.75 to 4 . The application of the conidia concentration of $1.3 \times 10^{6} \cdot \mathrm{m}^{-2}$, resulted in deformation of single sporophores with tissue discoloration in the case of CBS isolate, while most of the remaining isolates produced typical disease symptoms, that is, amorphic shapes, not resembling the health mushrooms, average scale of infection ranged from 1.5 to 4.0
(Table 1). By Kruskal-Wallis test a statistically significant $(P<0.05)$ difference in the severity of disease symptoms caused by $M$. perniciosa isolates tested was found (Table 1).

Type of disease symptoms and their development time were also examined by Kouser and Shah (2013) and Fletcher et. al (1989). They reported that when spores were applied at the time of casing, disease symptoms developed within 10-12 days. On the other hand, Gea et al. (2010) reported that the first symptoms of wet bubble were visible 18 days after the inoculation of casing with $10^{6}$ spores of M. perniciosa per $\mathrm{m}^{2}$.

Table 1 . Severity of symptoms of wet bubble disease depending on Mycogone perniciosa isolate and conidia concentration in the first flush of yield (average values from two series of experiment)

\begin{tabular}{|c|c|c|c|}
\hline \multirow{3}{*}{ Isolate } & \multicolumn{3}{|c|}{ Number of conidia per $\mathrm{m}^{2}$ casing } \\
\hline & $1.3 \times 10^{4} \cdot \mathrm{m}^{-2}$ & $1.3 \times 10^{5} \cdot \mathrm{m}^{-2}$ & $1.3 \times 10^{6} \cdot \mathrm{m}^{-2}$ \\
\hline & \multicolumn{3}{|c|}{ Average disease severity index } \\
\hline CBS & $0.0 \mathrm{c}$ & $0.0 \mathrm{c}$ & $0.5 \mathrm{c}$ \\
\hline M 19 & $0.0 \mathrm{c}$ & $0.5 \mathrm{c}$ & $1.5 \mathrm{~b}$ \\
\hline M 18 & $0.75 \mathrm{~b}$ & $2.75 \mathrm{~b}$ & $3.75 \mathrm{a}$ \\
\hline M1 & $2.0 \mathrm{a}$ & $3.37 \mathrm{a}$ & $4.0 \mathrm{a}$ \\
\hline M9 & $3.25 \mathrm{a}$ & $4.0 \mathrm{a}$ & $4.0 \mathrm{a}$ \\
\hline M11 & $0.75 \mathrm{~b}$ & $3.5 \mathrm{a}$ & $4.0 \mathrm{a}$ \\
\hline $\mathrm{H}^{*}$ & 26.16 & 43.69 & 32.64 \\
\hline
\end{tabular}

*Data are significant according to Kruskal-Wallis test at $\mathrm{p}=0.05$

Disease severity index evaluated according to a 0-4 scale, in which: 0 . no disease symptoms, 1 . single sporophores with disease symptoms, 2. 10-39\% of infected crop, 3. 40-69\% of infected crop, 4. 70-100\% of infected crop. Means in columns followed by the same letter are not significantly different using Dunn's test at $\mathrm{p}=0.05$

Our results showed that M1, M9, M11 and M18 isolates were more pathogenic than CBS and M19 isolates. At the application of low pathogenic isolates, disease symptoms were not observed or only single sporophores were infected, even when concentration was $1.3 \times 10^{6}$ spores per $\mathrm{m}^{2}$ of casing. Following the application of highly pathogenic isolates, even at the lowest number of spores, that is, $1.3 \times 10^{4} \cdot \mathrm{m}^{-2}$, large, very irregular, sclerodermoid masses of mushroom were formed, and disease severity was 2 or 3.25 (Table 1). Hsu and Han (1981) and Sharma and Kumar (2000), also reported on two 
main symptoms of wet bubble, that is, infected sporophores with the discoloration of tissue and brown tumor masses of mushrooms, as a result of the different severity of disease development.

The difference in the pathogenicity of M. perniciosa isolates resulted in a different degree of mushroom yield losses (Tables $2 \& 3$ ). The isolates M1, M9 and M11 caused $100 \%$ yield loss even when applied at the lowest spores concentration in the first and from 85 to $100 \%$ in the second series in comparison to not infected control. At the highest spores concentration all Polish isolates caused total yield loss in the first and almost total in the second series. The reference isolate CBS was least deleterious causing no more than $16.4 \%$ of yield loss. Mushroom yield obtained after the application of $M$. perniciosa isolates was highly correlated with disease symptoms severity, $\mathrm{r}=-0.777$ (Fig. 1).

Table 2. Percent of yield loss after infection of white button mushroom strain A15 with M. perniciosa (1. Series)

\begin{tabular}{lccc}
\hline Isolate & \multicolumn{3}{c}{ Number of conidia per $\mathrm{m}^{2}$ of casing } \\
\cline { 2 - 4 } & $1.3 \times 10^{4} \cdot \mathrm{m}^{-2}$ & $1.3 \times 10^{5} \cdot \mathrm{m}^{-2}$ & $1.3 \times 10^{6} \cdot \mathrm{m}^{-2}$ \\
\hline CBS & $1.1 \mathrm{~b}$ & $1.9 \mathrm{c}$ & $7.9 \mathrm{~b}$ \\
M19 & $3.6 \mathrm{~b}$ & $52.0 \mathrm{~b}$ & $100.0 \mathrm{a}$ \\
M18 & $5.1 \mathrm{~b}$ & $100.0 \mathrm{a}$ & $100.0 \mathrm{a}$ \\
M1 & $100.0 \mathrm{a}$ & $100.0 \mathrm{a}$ & $100.0 \mathrm{a}$ \\
M9 & $100.0 \mathrm{a}$ & $100.0 \mathrm{a}$ & $100.0 \mathrm{a}$ \\
M11 & $100.0 \mathrm{a}$ & $100.0 \mathrm{a}$ & $100.0 \mathrm{a}$ \\
\hline $\mathrm{H}^{*}$ & 19.48 & 19.45 & 33.20 \\
\hline
\end{tabular}

*Data are significant according to Kruskal-Wallis test at $\mathrm{p}=0.05$

Means in columns followed by the same letter are not significantly different using Dunn's test at $\mathrm{p}=0.05$

Table 3. Percent of yield loss after infection of white button mushroom strain A15 with M. perniciosa (2. Series)

\begin{tabular}{lccc}
\hline Isolate & \multicolumn{3}{c}{ Number of conidia per $\mathrm{m}^{2}$ of casing } \\
\cline { 2 - 4 } & $1.3 \times 10^{4} \cdot \mathrm{m}^{-2}$ & $1.3 \times 10^{5} \cdot \mathrm{m}^{-2}$ & $1.3 \times 10^{6} \cdot \mathrm{m}^{-2}$ \\
\hline CBS & $5.9 \mathrm{c}$ & $13.9 \mathrm{c}$ & $16.4 \mathrm{c}$ \\
M19 & $4.9 \mathrm{c}$ & $22.2 \mathrm{c}$ & $88.6 \mathrm{~b}$ \\
M18 & $11.5 \mathrm{c}$ & $70.4 \mathrm{~b}$ & $100.0 \mathrm{a}$ \\
M1 & $88.1 \mathrm{~b}$ & $100.0 \mathrm{a}$ & $100.0 \mathrm{a}$ \\
M9 & $100.0 \mathrm{a}$ & $100.0 \mathrm{a}$ & $100.0 \mathrm{a}$ \\
M11 & $85.0 \mathrm{~b}$ & $100.0 \mathrm{a}$ & $100.0 \mathrm{a}$ \\
\hline $\mathrm{H}^{*}$ & 25.90 & 29.10 & 29.60 \\
\hline
\end{tabular}

Note: see Table 2

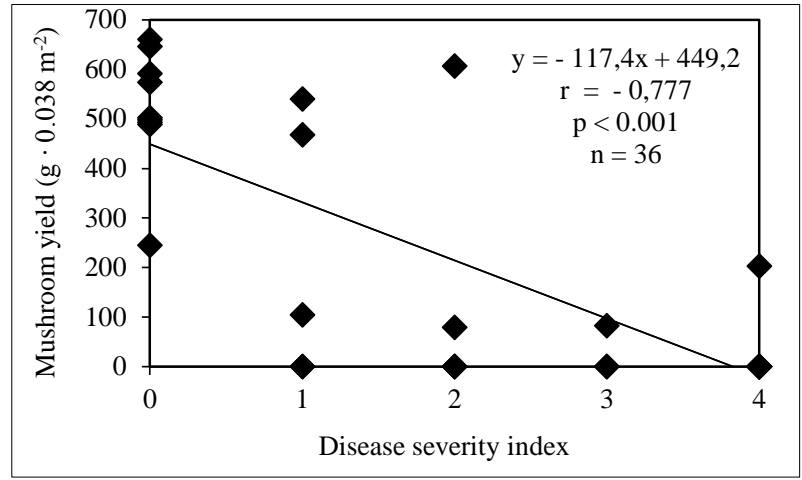

Fig. 1. Relationship between the disease development (on a 0-4 scale) and mushroom yield

A high severity of disease in our results is in accordance with those recorded by Sharma and Kumar (2000), Bhatt and Singh (2002) and Singh and Sharma (2002). They also observed the yield losses ranging from $65.6,80.1$ and $100 \%$ after the inoculation of casing with $M$. perniciosa isolates. On the other hand, Gea et al. (2010) reported that the incidence of the disease in the inoculated control was $30.6 \%$ in the first flush, in trial with dose containing $10^{6}$ spores per $\mathrm{m}^{2}$. It shows that tested isolates of $M$. perniciosa in our study were highly pathogenic to A15 strain of A. bisporus.

Variability in the pathogenicity of $M$. perniciosa isolates can be attributable to the presence of mycoviruses in hyphae of these isolates (Fletcher et al. 1995; Lapierre et al. 1971; Umar et al. 2000). Umar et al. (2000) observed intracellular virus-like particles in scanning electron microscope. Fletcher et al. (1995) recorded that virus-containing strains of $M$. perniciosa grew slower and induced typical symptoms of wet bubble that is, sclerodermoid mushrooms. The fast-growing isolates did not contain virus-like particles and caused only cap spotting. On the other hand, Szumigaj-Tarnowska et al. (2013a) did not observe significant differences in the growth rate among isolates tested. Lapierre et al. (1971) found that some pathogenic strains, which were slow-growing on agar, were highly pigmented and produced numerous aleuriospores. Others were weakly pathogenic, producing much vegetative growth and little pigmentation. The slow-growing forms were found to contain numerous virus-like particles of $39 \mathrm{~nm}$ diameter. Our research concern- 
ing colony pigmentation on agar medium and pathogenicity of the isolates showed that CBS isolate (a weakly pathogenic against A15 strain of A. bisporus) is characterised with a slow-growing and little pigmented colony, while M9 (strongly pathogenic isolate) and M19 (weakly pathogenic) produced equally brown pigmented colony agar media. Atkey et al. (1976) and Fletcher et al. (1995) found that all studied isolates were highly pathogenic irrespective of the growth rate and virus particle content. It seems that the virulence in $M$. perniciosa isolates reveal a complex interaction between genotypes of pathogen and the host.

In two series of experiment a similar tendency in pathogenicity against A. bisporus of the tested isolates was observed (i.e. CBS and M19 were characterised by the weakest pathogenicity) although in the second series the isolates M1 and M11 showed lower virulence against mushroom A15 than in the first one. It can be explained by possible differences in physico-chemical properties of the compost and highly sensitive reaction of mushroom on growth conditions which affected resistance to pathogens. These and other experimental data confirm thesis that both the resistance of host and virulence of pathogen are highly depended on the particular life conditions.

\section{CONCLUSION}

The isolates of $M$. perniciosa derived from different mushroom plantations significantly varied in pathogenicity against strain A15 of mushroom, which had an influence on the yield losses in the experiments. Depending on the pathogenicity of a isolate, the various disease symptoms and disease severity were observed. Casing surface inoculation with low pathogenic M. perniciosa isolates did not cause disease symptoms in the first flush or produce slight deformation of sporophores, even at high spores concentration $\left(1.3 \times 10^{6} \cdot \mathrm{m}^{-2}\right)$. The isolates of high pathogenicity caused $100 \%$ yield loss even at inoculation with the spores at the concentration $1.3 \times 10^{4} \cdot \mathrm{m}^{-2}$.

\section{Acknowledgments}

This study was supported by the National Science Centre for the years 2011-2014 as research project No. NN 310 733140 .

\section{REFERENCES}

Atkey P.T., Barton R.J., Gandy D.G. 1976. Virus of the mushroom pathogen Mycogone perniciosa. Annual Report - Glasshouse Crops Research Institute, Little-Hampton, England, p. 127.

Bhatt N., Singh R.-P. 2002. Chemical control of mycoparasites of button mushroom. Journal of Mycology and Plant Pathology 32 (1): 38-45.

Fletcher J.T., Drakes G.D., Talent C.J.W. 1975. The control of wet bubble disease of mushrooms caused by $M y$ cogone perniciosa. Annals of Applied Biology 79(1): 35-41. DOI: 10.1111/j.1744-7348.1975.tb01519.x.

Fletcher J.T., Ganney G.W. 1968. Experiments on the biology and control of Mycogone perniciosa Magnus. Mushroom Science 7: 221-237.

Fletcher J.T., Jaffe B., Muthumeenakshi S., Brown A.E., Wright D.M. 1995. Variations in isolates of Mycogone perniciosa and in disease symptoms in Agaricus bisporus. Plant Pathology 44(1):130-140. DOI: 10.1111/j.1365-3059.1995.tb02725.x.

Fletcher J.T., White P.F., Gaze R.H. 1989. Mushrooms: pest and diseases control. 2nd ed. Intercept Andover, UK, pp. 174.

Gea F.J., Tello J.C., Navarro M.-J. 2010. Efficacy and effects on yield of different fungicides for control of wet bubble disease of mushroom caused by the mycoparasite Mycogone perniciosa. Crop Protection 29: 1021-1025. DOI: 10.1016/j.cropro.2010.06.006.

Glamočlija J., Soković M., Ljaljević-Grbić M., Vukojević J., Milenković I., van Griensven L.J.L.D. 2008. Morphological characteristic and mycelia compatibility of different Mycogone perniciosa isolates. Journal of Microscopy 232(3): 489-492. DOI: 10.1111/j.1365-2818.2008.02145.x.

Hsu H.K., Han Y.S. 1981. Physiological and ecological properties and chemical control of Mycogone perniciosa Magnus causing wet bubble in cultivated mushrooms. Mushroom Science 11: 403-425.

Kouser S., Shah S. 2013. Isolation and identification of Mycogone perniciosa, causing wet bubble disease in Agaricus bisporus cultivation in Kashmir. African Journal of Agricultural Research 8(38): 48044809. DOI: 10.5897/AJAR2013.6808.

Lapierre H., Faivre-Amiot A., Kusiak C., Molin G., Keusseoglou J., Albouy J., Bondoux P., Morand J.C. 1971. Virus-like particles associated with the species of Mycogone perniciosa. Annals of Phytopathology 3: 538 .

Maszkiewicz J. 2001. Efficacy of chlorothalonil fungicide (Gwarant $500 \mathrm{SC}$ ) against wet bubble of champignon (Mycogone perniciosa), dry bubble of 
champignon (Verticillium fungicola) and dactylium (Dactylium dendroides). Vegetable Crops Research Bulletin 55: 131-135.

Maszkiewicz J., Dyki B. 1988. Wet bubble disease of mushrooms (Mycogone perniciosa Magn.). Preliminary description of symptoms, the causing agent and the influence of the disease on the yield. Biuletyn Warzywniczy 32: 177-187. [in Polish with English abstract]

Potocnik I. 2006. Morphological and pathogenic characteristics of the causal agents of dry and wet bubble diseases of white button mushroom (Agaricus bisporus (Lange) Imbach) in Serbia. Pesticidi i Fitomedicina 21(4): 289-296.

Sharma S.R., Kumar S. 2000. Studies on wet bubble disease of white button mushrooms (Agaricus bisporus) caused by Mycogone perniciosa. Mushroom Science 15: 569-575.

Sharma S.R., Kumar S. 2005. Diseases of mushrooms and their management. (250-251). In: Challenging problems in horticultural and forest pathology. Sharma R.C. \& Sharma J.N. (Ed.). Indus Publishing Company, New Delhi, pp. 246-288.

Singh C., Sharma V.-P. 2002. Occurrence of wet bubble disease of white button mushroom (Agaricus bisporus). Journal of Mycology and Plant Pathology 32(2): 222-224.

Smith F.E.V. 1924. Three diseases of cultivated mushrooms. Transactions of the British Mycological Society 10: 81-97. DOI: 10.1016/S0007-1536(24)80007-4.

Szudyga K. 2015. Rok 2014. Biuletyn Producenta Pieczarek - Pieczarki 1: 6-8. [in Polish]
Szumigaj-Tarnowska J., Uliński Z., Ślusarski C. 2012. Assessment of effectiveness of biological agents in the control of fungal diseases of the white button mushrooms. Progress in Plant Protection/Postępy w Ochronie Roślin 52(4): 963-968. [in Polish with English abstract]

Szumigaj-Tarnowska J., Szczechura W., Uliński Z., Ślusarski C., Staniaszek M. 2013a. Characterization of pathogenic isolates of Mycogone perniciosa derived from polish mushroom houses. 5th Congress of European Microbiologists, Leipzig, Germany, 21-25 July 2013, pp. 221.

Szumigaj-Tarnowska J., Wrzodak A., Uliński Z., Ślusarski C. 2013b. Susceptibility to wet bubble of various white button mushroom strains Agaricus bisporus and sensory assessment of their fruiting bodies. Zeszyty Naukowe Instytutu Ogrodnictwa 21: 105115. [in Polish with English abstract]

Ślusarski C., Uliński Z., Szumigaj-Tarnowska J. 2012. A survey of the sanitary conditions and the occurrence of infectious diseases on Polish mushroom farms. Progress in Plant Protection/Postępy w Ochronie Roślin 52(4): 1052-1057. [in Polish with English abstract]

Umar M.H., Geels F.P., van Griensven L.J.L.D. 2000. Pathology and pathogenesis of Mycogone perniciosa infection of Agaricus bisporus. Mushroom Science 15: 561-567.

Van Zaayen A., Van Adrichem J.C.J. 1982. Prochloraz for control of fungal pathogens of cultivated mushrooms. Netherlands Journal of Plant Pathology 88: 203-213. 